\title{
Profit distribution and regulation: the impact of mandatory dividend in corporate internal funding
}

\author{
Daniel Francisco Vancin ${ }^{1}$ \\ (D) https://orcid.org/0000-0001-6303-0555 \\ E-mail: daniel_vancin@hotmail.com \\ Guilherme Kirch² \\ (D) https://orcid.org/0000-0002-8311-6863 \\ E-mail: gkirch@ufrgs.br
}

1 Universidade do Vale do Rio dos Sinos, Escola de Gestão e Negócios, Departamento de Ciências Contábeis, Porto Alegre, RS, Brazil
${ }^{2}$ Universidade Federal do Rio Grande do Sul, Escola de Administração, Departamento de Ciências Administrativas, Porto Alegre, RS, Brazil

Received on 05.21.2019 - Desk acceptance on 06.25.2019 - $2^{\text {nd }}$ version approved on 10.11.2019 - Ahead of print on 03.02.2020

Associate Editor: Fernanda Finotti Cordeiro Perobelli

\begin{abstract}
The purpose of our research is to verify the impact of mandatory dividends on Brazilian publicly traded companies, focusing on both the value of cash holdings and the impact on corporate investment. Our work aims to reach the research objective making significant improvements over the previous works on the subject. First, we separate firms according to their dividend status. Second, in addition to investment regressions, we use the value of cash approach to test the impact of mandatory dividend on corporate financial decisions. Finally, our manual data collection makes it possible to allocate the dividend distributed to its reference period. Considering our context, where sources of financing are expensive and scarce, evidences obtained by the present research has great relevance. The law aims to protect the minority investor against the expropriation of resources. However, in dealing with all cases equally, legislation ends up harming companies that rely on these resources for their financing, thereby damaging their shareholders. This article brings new evidences, from an innovative approach, on factors affecting the availability of resources and its impact on the value of cash and on corporate investment in Brazil. We analyzed a sample of 1,654 dividend distributions from 2008 to 2015, using investment and firm value regressions. Our results indicate that companies paying just the minimum dividend have higher value attached to an extra unit of cash, corroborating our view that those companies will likely use these resources to fund future profitable investments. We also find that mandatory dividend has a negative impact on investment, but only for companies paying dividends above the minimum, contrary to our expectations. We argue that the marginal value of cash approach is a more effective way to test the impact of regulation on corporate financial decisions and this last evidence may be the result of endogeneity problems in investment regressions.
\end{abstract}

Keywords: mandatory dividend, internal funding, value of cash, investment, financial constraints.

Correspondence address 


\section{INTRODUCTION}

According to Vancin and Procianoy (2016), Brazilian reality regarding low availability of long-term resources to finance investment activities is a great incentive for high retention of cash by companies. Therefore, in general, internal financing has great importance for national company's investment policy.

Specifically in Brazil, one legal feature can impact directly on the availability of firm's internal funds: the mandatory dividend. In Brazil, firms are obligated by law to distribute a minimum share of their profits. The purpose of establishing a minimum mandatory dividend seems to be the protection of minority shareholders, by preventing the controller from retaining all profits, and thus to promote the development of the capital market (Coelho, 2002; La Porta, Lopez-de Silanes, Shleifer, \& Vishny, 1998, 2000; Souza, Peixoto, \& Santos, 2016).

However, mandatory dividend rules remove part of the management discretion over the use of its internal resources. This means a reduction in cash flow available to companies, which could be used, among other things, for investments in profitable projects (Martins \& Novaes, 2012). In addition, firms whose dividend constraint is binding are likely financial constrained. According to Faulkender and Wang (2006), these firms are more prone to use their cash reserves to avoid the higher costs or raising money from external capital markets. Therefore, investors may place a higher value on cash reserves of such firms.

Thus, compulsory distribution of company's profits may have impact on company's investments and/or on how investors value firm's cash reserves. The purpose of our research is precisely to verify the impact of mandatory dividends on Brazilian publicly traded companies' internal funding, focusing on both the value of cash holdings and the impact on corporate investment.

In order to achieve this goal, we star our research from the premise that there is a basic difference between companies paying the minimum mandatory dividend and those paying above this amount. According to Vancin and Procianoy (2016), the formers are compelled by law to make some payment of dividends. If they could pay less than this obligatory amount, they would probably do so. The desire to pay is only found in those who pay above this minimum.

One reason why companies pay only the mandatory minimum may be financial constraints: with limited internal resources and costly external finance, firms cut profitable investments and set dividends to the minimum allowed in order to satisfy their budget constraints. In anticipation of future financial constraints, firms may also save cash today in order to be able to invest more in the future (Acharya, Almeida, \& Campello, 2007; Almeida, Campello, \& Weisbach, 2004). In these situations, corporate investment may be sensible to internal funds and the amount of mandatory dividends. In addition, cash holdings of firms facing financial constraints should have a higher value, since their likely use is to fund future value-enhancing investments (Faulkender \& Wang, 2006).

On the other hand, there are companies that, by their own criteria, decide to distribute dividends above the mandatory minimum. If we admit that the dividend above minimum (discretionary) is residual, that is, would be the amount left over after all acceptable investment opportunities have been taken, the mandatory dividend of companies paying above minimum should not have an impact on their investments, after controlling for its other determinants. At the same time, cash holdings of those firms should have a lower value, since their likely use is to increase distributions to equity or pay down debt (Faulkender \& Wang, 2006).

In summary, our main assumption is that companies plan the discretionary distribution based on their capital budgets. Consequently, for companies that pay just the minimum dividend, financial constraints are likely to be binding. For those firms we expect that: (i) cash holdings have a higher value at the eyes of investors (relatively to firms that pay dividends above minimum); and (ii) investments are negatively affected by the amount of mandatory dividends.

Using a sample of Brazilian publicly traded firms and hand collected data about the dividends decisions and policies of each firm, we estimate investment and firm value regressions like Fazzari, Hubbard, and Petersen (1988) and Faulkender and Wang (2006), respectively, augment by terms related to the mandatory dividend and the decision to pay just the minimum. Our evidences clearly suggest that companies paying just the minimum dividend have higher value attached to an extra unit of cash. This fact probably denotes a greater dependence on internal sources for investment and financing in these companies. Contrary to our expectations, our results also indicate that mandatory dividend has a negative impact on corporate investment, but only for firms that pay dividends above the mandatory.

Previously, Martins and Novaes (2012) tested the impact of dividends on investment of Brazilian publicly 
traded companies. These authors concluded that the mandatory dividend law is effective, as the dividend yield in Brazil is superior to the one verified in the United States of America, without making the investment of Brazilian firms more difficult. This research pioneered the investigation of the topic and helped to begin elucidating the problem.

Our work aims to reach the research objective making significant improvements over the previous works on the subject. First, different from Martins and Novaes (2012), we separate firms (in each year) according to their dividend status: those paying just the mandatory minimum and those paying above the minimum. As we argued above, only the investments of the first group should be affected by the mandatory dividend. Since dividends above the mandatory minimum are prevalent in our sample of publicly traded firms, is not a surprise that Martins and Novaes (2012) did not find a significant effect of dividends on corporate investments.

Second, our manual data collection (which will be described later in section 3) makes it possible, with unprecedented accuracy, to allocate the dividend distributed to its reference period, that is, the fiscal year in which this profit was generated, and not to its payment period. As a direct consequence, empirical models will be more accurate to test the impact of mandatory dividend on corporate investment.
Finally, we obtain evidences on the effects of mandatory dividend rules on corporate decisions looking at the value shareholders place on companies' cash. According to Faulkender and Wang (2006), the marginal value of cash (MVC) should depend on its most likely use. We claim that the most likely use can be inferred from the firm dividend decision to pay just the mandatory minimum or pay above it. A constrained firm that pays just the mandatory minimum will likely spend cash in valueenhancing investment, while an unconstrained firm that pays above the mandatory minimum will likely use cash to pay down debt or increase distributions to shareholders. Since investment and dividend decisions are made by the same persons (directors and board of managers), one can argue that dividends, even though determined in part by law, are not exogenous in a firm investment regression. This same criticism loses much of its strength when we look at the MVC, because of value is set by capital market participants and not by the persons who determine the amount of dividends of the firm. We believe that this approach is a more effective way to evaluate the impact of regulation on corporate decisions.

The next section presents the hypotheses, the empirical models, and methods of estimation. Section 3 describes data collection and our sample. The results of this study are reported and discussed in section 4 . The final section synthesizes the conclusions of the study.

\section{RESEARCH DESIGN}

In a perfect world, investment should depend only on firm's investment opportunities. In the real world, characterized by several imperfections, like asymmetric information, transaction costs, taxes, etc., investment may be sensible to the availability of internal funds (Fazzari et al., 1988). Gilchrist and Himmelberg (1995) point that several studies emphasize that investment is highly correlated with cash flow or other measures of internal funds. According to these authors, this correlation appears in models that contemplate imperfections in the capital market, either because of the investment is directly linked to the internal funds available in the case of credit rationing, or because of shocks in current profit affect the equity future liquidity and, therefore, terms of credit available to companies.

In this context, companies have two basic alternatives for allocating the results of their activities: to distribute the surplus profits to their shareholders or to invest them in profitable projects that will result in more profits for shareholders (at least in expectation). In this issue lies an important financial decision of the managers: pay dividends and thus reward shareholders for their capital invested or not distribute and thus demonstrate confidence in their investment opportunities that could be lost if dividends were paid. In a context where there is no obligation to distribute dividends, whether for legal or contractual reasons, if the company wishes, cash flow can be used in full in new investments.

Specifically in Brazil, the legislation imposes a minimum compulsory distribution of dividends, that is, Brazilian companies are compelled by law to distribute part of their internal resources. In addition, this obligation does not consider different realities faced by companies. Does not consider, for example, whether this share of internal resources would affect corporate investment, or if companies have other forms of financing, among other possibilites. The law affects all firms equally, despite the different financial realities experienced by each of the Brazilian companies.

Faulkender and Wang (2006) argue and provide evidences that the MVC to shareholders depends on the 
likely use of this cash. According to these authors (p. 1958): "for firms that face greater financing constraints, especially those with valuable investment opportunities, the MVC should be higher than for firms that can easily raise additional capital". Firms facing financing constraints are more likely to use an additional dollar of internal funds in value-enhancing investment opportunities and thus shareholders will place a higher value on their cash reserves.

We argue that companies that have paid dividends above minimum are non-financially constrained, since they choose to use a portion of free cash flow for earnings distribution. These companies indicate to the market that they have more than enough resources to make their viable investment projects, as they demonstrate that they have "idle" resources for extra distribution to their shareholders. However, companies that pay only the mandatory dividend can be considered financially constrained, since they only distribute the minimum necessary to comply with the legislation, i.e., they demonstrate that they need all the free cash flow for the company's activities.
If a binding dividend constraint really results from financial constraints, we should expect that shareholders will place a higher value on cash reserves of firms that pay just the minimum mandatory dividend than on cash reserves of firms that pay above this amount. This reasoning leads to our first hypothesis:

$\mathrm{H}_{1}$ : all else constant, the MVC decreases with the payment of dividends above the mandatory minimum.

To test this hypothesis, we take the model of Faulkender and Wang (2006) as reference. These authors, based on the studies of Fama and French (1998) and Pinkowitz and Williamson (2004), developed an empirical model to measure the marginal value that market investors place on the company's cash. As we aim to measure how this MVC varies with dividend status, we augment the main empirical model estimated by Faulkender and Wang (2006) by including interactions between changes in cash and discretionary dividends (dividends above the mandatory minimum). Thus, we estimate the following model with firm and year fixed effects:

$$
\begin{gathered}
r_{i, t}-R_{i, t}=\alpha_{1} \frac{\Delta C_{i, t}}{M_{i, t-1}}+\alpha_{2} \frac{\Delta E_{i, t}}{M_{i, t-1}}+\alpha_{3} \frac{\Delta N A_{i, t}}{M_{i, t-1}}+\alpha_{4} \frac{\Delta R D_{i, t}}{M_{i, t-1}}+\alpha_{5} \frac{\Delta I_{i, t}}{M_{i, t-1}}+\alpha_{6} \frac{\Delta D_{i, t}}{M_{i, t-1}}+ \\
\alpha_{7} \frac{C_{i, t-1}}{M_{i, t-1}}+\alpha_{8} L_{i, t}+\alpha_{9} \frac{\Delta N F_{i, t}}{M_{i, t-1}}+\alpha_{10} \frac{C_{i, t-1}}{M_{i, t-1}} \times \frac{\Delta C_{i, t}}{M_{i, t-1}}+\alpha_{11} L_{i, t} x \frac{\Delta C_{i, t}}{M_{i, t-1}}+ \\
\alpha_{12} \frac{\Delta C_{i, t}}{M_{i, t-1}} \times D i v D_{i, t}+\mu_{i}+\mu_{t}+\epsilon_{i, t}
\end{gathered}
$$

where $\mathrm{r}_{\mathrm{i}, \mathrm{t}}$ is the stock return for firm $i$ during fiscal year $t, \mathrm{R}_{\mathrm{i}, \mathrm{t}}$ is the stock $i$ 's benchmark return at year $t, \mathrm{M}_{\mathrm{i}, \mathrm{t}-1}$ is the one-year lagged ( $t-1)$ market value of equity, $\Delta \mathrm{C}_{\mathrm{i}, \mathrm{t}}$ measures the change in cash holdings for firm $i$ during fiscal year $t, \Delta \mathrm{E}_{\mathrm{i}, \mathrm{t}}$ is the change in the firm's profitability (earnings before interest and extraordinary items), $\Delta \mathrm{NA}_{\mathrm{i}, \mathrm{t}}$ is the change in total assets net of cash, $\Delta \mathrm{RD}_{\mathrm{i}, \mathrm{t}}$ is the change in research and development $(\mathrm{R} \& \mathrm{D}), \Delta \mathrm{I}_{\mathrm{i}, \mathrm{t}}$ measures changes in interest expenses, $\Delta \mathrm{D}_{\mathrm{i}, \mathrm{t}}$ is the change in total dividends, $\mathrm{C}_{\mathrm{i}, \mathrm{t}-1}$ is the cash holdings for firm $i$ during fiscal year $t-1, \mathrm{~L}_{\mathrm{i}, \mathrm{t}}$ measures leverage at the end of fiscal year $t$, the ratio of the total liabilities and assets of a company, $\mathrm{NF}_{\mathrm{i}, \mathrm{t}}$ is the firm's net financing during the fiscal year $t$ measured by the total issued shares plus total issued debt less repurchases and total debt redemption, and $\mathrm{DivD}_{\mathrm{i}, \mathrm{t}}$ measures the amount of the discretionary dividend relative to the mandatory dividend.

We also use a discretized version of our discretionary dividend variable that we dubbed Dummy $\mathrm{i}_{\mathrm{i},}$. This variable takes value 1 if discretionary dividend is positive, and 0 otherwise. Our argument is that firm that pay above the minimum are not financially constrained, will likely use cash to increase distributions to equity or pay down debt, and so investor will place a lower value on their cash holdings (Faulkender \& Wang, 2006). Note that our argument is based only in the distinction between those firms paying above and those paying just the minimum mandatory dividend. This is the role played by our Dummy $y_{i, t}$ variable. Moving a step forward, we also examine whether the intensity with which the firm pays dividends above the mandatory minimum affects its MVC. For this purpose we use the continuous variable DivD $\mathrm{D}_{\mathrm{i}, \mathrm{t}}$.

The dependent variable is the percentage return of firm $i$ stock subtracted from the return of the main reference index from the Brazilian stock exchange (Brasil Bolsa Balcão - B3): Indice Bovespa (Ibovespa). Faulkender and Wang (2006) use the 25 Fama and French portfolios formed on size and book-to-market as their benchmarks. Thus, for stock $i$, the benchmark return, in their case, is the return of the portfolio to which stock $i$ belongs. The benchmark return should represent the expected return of stock $i$ and so the dependent variable is the excess stock return. We opt for Ibovespa as the benchmark because it is the most important index of the Brazilian stock market, 
and broad market portfolios are the most relevant factors in explaining individual and portfolio stock returns in this context [see, for example, Machado and Medeiros (2011) and Noda, Martelanc, and Securato (2014)].

The selected explanatory variables are controls of value sources besides money, but which are correlated with company's retention of cash, according to Faulkender and Wang (2006). The use of variations $(\Delta)$ in control variables serves to indicate unexpected changes in a variable that correlates with retention of money in companies.

As mentioned above, we use interaction terms in the model to test our first hypothesis. We use the term $\alpha_{12}\left(\Delta C_{i, t} \times D_{i v D_{i, t}}\right)$ to estimate the effect of the payment of extra dividends on the value of firm cash. According to our hypothesis, $\alpha_{12}$ is expected to be negative, indicating that the MVC reserves decreases as the company decides to distribute more discretionary dividends.

After the estimation of the proposed model, we are able to measure the sensitivity of additional value (AV), that is, returns in excess to the market benchmark to variations on cash holdings. This step has the purpose of directly measure the AV linked to the variation in cash, i.e., how much value is assigned by the financial market to an additional cash unit $(\Delta \mathrm{C})$. The calculation is performed through the first derivative of $\mathrm{AV}$ with respect to $\Delta \mathrm{C}$ and is demonstrated in equation 2.

$$
M V C=\frac{\partial A V}{\partial \Delta C}=\alpha_{1}+\alpha_{10} C_{i, t-1}+\alpha_{11} L_{i, t}+\alpha_{12} D_{i v} D_{i, t}
$$

The minimum dividend constraint imposed by law may be binding for some firms, due to their financial realities and investment opportunities, and thus we can expect that their investment and financial decisions may change relative to what would be in the absence of such constraint. Vancin and Procianoy (2016) state that there is a basic difference between the companies that pay the minimum mandatory dividend and those that pay above this amount. It is observed that the former are compelled by law to make some payment of dividends. If they could pay less than these obligatory, they would probably do so. The desire to pay is only found in those who pay above these minimums.

If a binding dividend constraint is the outcome of financial restrictions, we should expect a negative and significant effect of mandatory dividend on investment for those firms that pay just this amount.
In this situation, mandatory dividends may force firms to cut investments. For companies that pay above the minimum, the mandatory dividend should not have an impact on investment (just as the dividend above the mandatory - the discretionary part - should not have), since these firms are not financially constrained. In other words, all else equal, we expect that firms that pay just the mandatory dividend invest less than firms that pay dividends above the mandatory minimum, that is, whose dividend constraint is not binding. This reasoning leads to our second hypothesis:

$\mathrm{H}_{2}$ : minimum mandatory dividend reduces the level of investment of restricted companies, that is, those that distribute only the mandatory dividend.

In order to verify this hypothesis empirically, the following multiple regression model is estimated:

$$
\operatorname{Inv}_{i, t}=\alpha_{1} C F_{i, t}+\alpha_{2} Q_{i, t-1}+\alpha_{3} M D i v_{i, t-1}+\alpha_{4} M D i v_{i, t-1} \times \min _{i, t-1}+\mu_{i}+\mu_{t}+\varepsilon i, t
$$

where $\operatorname{Inv}_{\mathrm{i}, \mathrm{t}}$ is the dependent variable that represents the companies' investment. It is measured by the ratio between firm's capital expenditure in period $t$ and total assets in period $\mathrm{t}-1 . \mathrm{CF}_{\mathrm{i}, \mathrm{t}}$ is the cash flow generated by firm $i$ over period $t$. This variable represents the resources generated internally, being measured by the ratio between earnings before interest, taxes, depreciation and amortization (EBITDA) in period $t$ and total assets in period $\mathrm{t}-1$. $\mathrm{Q}_{\mathrm{i}, \mathrm{t}-1}$ represents investment opportunities of firm $i$ at the beginning of period $t$, obtained by the ratio between market value and book value of assets, the first being the sum of total assets and market value of the shares minus the value of net worth. $\mathrm{MDiv}_{\mathrm{i}, \mathrm{t}-1}$ is the mandatory dividend.

More specifically, $\mathrm{MDiv}_{\mathrm{i}, \mathrm{t}-1}$ measures how much the mandatory dividend represents of the firm cash flow.
It is calculated by the ratio between the amount of the mandatory dividend distributed by the company and its EBITDA. We chose to estimate this variable with lag for two main reasons: (i) to avoid correlation with cash flow variable and (ii) by reading the minutes of the companies' ordinary general meeting (OGM). It was observed that, normally, the distributed dividend in $t$ refers to the profit generated in $\mathrm{t}-1$ by the companies. Finally, $\min _{\mathrm{i}, \mathrm{t}-1}$ is a dummy variable that indicates whether the mandatory dividend constraint is binding. It receives the value of 1 if the company distributes only the mandatory dividend in the previous year, and 0 otherwise.

According to $\mathrm{H}_{2}, \alpha_{4}$ should be negative and statistically significant, indicating that the higher is the fraction of mandatory dividend relative to firm cash flow, the lower 
is the investment of binding dividend constraint firms. As in previous studies, Tobin's $\mathrm{Q}$ and cash flow should attract positive coefficients, since better investment opportunities and more internal resources foster corporate investment (Abel \& Eberly, 2011; Fazzari \& Petersen, 1993; Fazzari et al., 1988; Gilchrist \& Himmelberg, 1995; Hubbard, 1997; Lewellen \& Lewellen, 2016).

An important criticism in the literature on investmentcash flow sensitivities is the bias due to measurement errors in the investment opportunity variable (Tobin's Q). Critics argue that cash flows only captures the effects of the set of investment opportunities not perfectly measured by Tobin's $\mathrm{Q}$, and therefore contest that cash flows would influence the firms' investment demand by a financial constraint motive (Fazzari, Hubbard, \& Petersen, 2000; Gomes, 2001; Kaplan \& Zingales, 1997, 2000). We believe that our proposal of including an interaction between mandatory dividend and binding dividend constraint can overcome this criticism, since this interaction should capture firms' financial constraints and it is not related to investment opportunities not captured by Tobin's Q and cash flows.

\section{DATA COLLECTION AND SAMPLE}

The sample is composed of Brazilian companies listed on B3 in the period from 2008 to 2015, with financial companies excluded from the sample. The data related to financial statements, market value, and stock returns of these companies was extracted from the database of Economatica ${ }^{\mathbb{R}}$.

In order to test our hypothesis, we need to classify Brazilian publicly traded companies among companies that pay dividends above mandatory minimum and companies that only pay this amount. Legislation determines that company's bylaws may establish the minimum portion of profit distributed via dividends. If company bylaws is silent about this matter, the mandatory dividend is the one established in the law: 50\% of adjusted net profit. Given this legal provision, the analysis of bylaws of companies listed on B3 becomes necessary for the fulfillment of the objectives of this work.

Thus, by analyzing bylaws of Brazilian publicly traded companies, we collect which portion of the adjusted net profit should be earmarked for mandatory payment of dividends for each one of them. In order to verify whether it was being paid or not, we used the article 192 of Brazilian corporate law (Lei n. 6.404/1976), which determines that the OGM must approve the proposed allocation of net income for the year. Therefore, was imperative to us read the minutes of the OGMs that approved the allocation of dividends, in order to relate dividends paid to the fiscal year that gave rise to them.

A total of 2,768 minutes of companies listed on B3 in the period from 2008 to 2015 were analyzed. After reading the minutes, a comparison was made between how much was approved by the OGM and how much, according to the legislation and bylaws of each company, should be allocated to shareholders as mandatory dividend. By making such a comparison, we can determine which companies are paying just the required or above it. Of this 2,768 dividend distributions, 668 were excluded for being banks or financial institutions and 446 for not having full data, resulting in a final unbalanced panel sample of 1,654 firm-year observations, from 293 firms.

One can argue that mandatory dividend is not entirely exogenous, since it can be changed by a change in firm bylaws. Therefore, we eliminate from the sample those companies that have a mandatory dividend lower than $25 \%$ of adjusted net profit (minimum amount determined by law if the firm wants to offer a share of profits to their managers) in their bylaws. At the end of 2012, 82.1\% of Brazilian publicly-traded companies used in their bylaws the proportion of $25 \%$ of adjusted net income as mandatory dividend (Vancin, 2013).

To better describe the sample, we created Figure 1 in order to demonstrate the existing payout pattern in Brazilian companies. From its analysis, we can observe, in general terms, that the proportion of profits distributed to the shareholders of Brazilian publicly traded companies is stable. For all companies in the sample, it is observed that over the period selected for the sample the average payout varied very little - the same occurring for the specific group of companies that distributed dividends above the mandatory minimum. One of the possible explanations is the managers' fear of cutting dividends (informational content) and thus would have incentives to keep these payments constant. In the group of companies that distribute only the minimum, this observed stability is even stronger. 


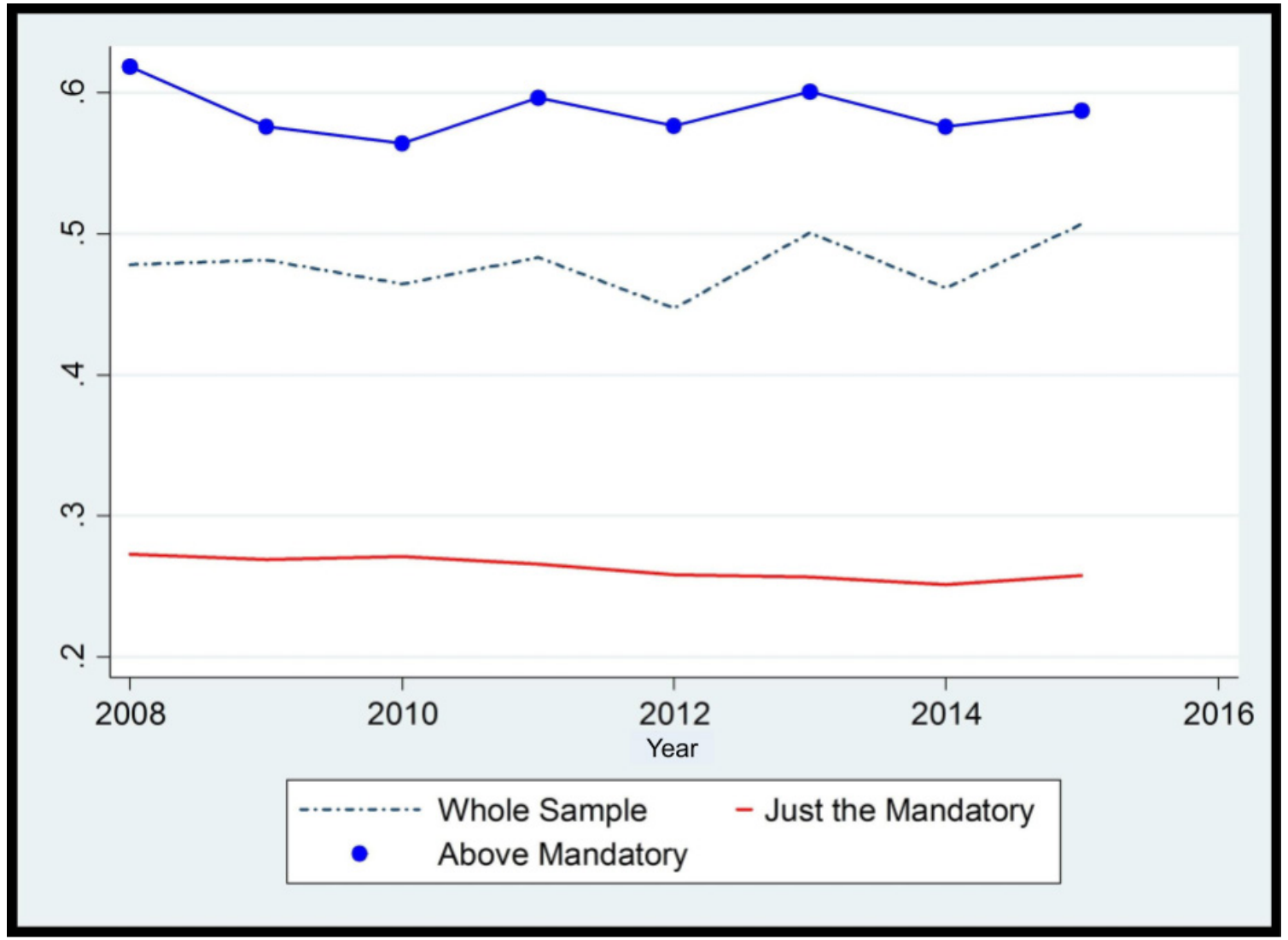

Figure 1 Temporal evolution of dividend payments in Brazil

Note: The chart is divided into three groups: Whole sample reflects the data for all sample companies, Just the mandatory, those who distributed only the minimum mandatory dividend, and Above mandatory, those who distributed above the minimum.

Source: Elaborated by the authors.

Finally, atypical observations (outliers) should receive attention when performing multiple regressions. These extreme data can significantly influence the estimation of the parameters of the models. To eliminate such influence, we winsorize our variables at the 5 and $95 \%$ percentiles.

\section{MAIN EMPIRICAL RESULTS}

In this section, we present our main results. We start by commenting the descriptive statistics of our variables and then we test our hypotheses based on the estimations of models 1 and 3.

\subsection{The Impact of the Mandatory Dividend on $\mathrm{MVC}-\mathrm{H}_{1}$}

An econometric model was developed and estimated in order to test the impact of the mandatory dividend on the marginal value of the companies' cash. The variables selected for this model are basically controls of value sources for the company and that are correlated with the retention of money, according to Faulkender and
Wang (2006). As explained previously in the present research, the sample is composed of Brazilian publicly traded companies (except financial companies) in the period from 2008 to 2015 . The descriptive statistics are summarized in the Table 1.

According to the data in this table, Brazilian companies had an average increase in the amount of cash $\left(\Delta \mathrm{C}_{\mathrm{i}, \mathrm{t}}\right.$ positive) in this period. We infer a possible precaution of the management of Brazilian publicly-traded companies, since during the analyzed period the intention was to maintain larger amounts of resources within the companies. An explanation for this fact stems from the cycles of crisis and uncertainty that hovered over Brazil in the period. 
Table 1

Descriptive statistics of variables selected for $\mathrm{H} 1 \mathrm{model}$

\begin{tabular}{|c|c|c|c|c|c|}
\hline Variable & Obs. & Average & $\sigma$ & Min. & Max. \\
\hline$A V_{i, t}$ & 1,654 & 0.052 & 0.537 & -1.302 & 2.221 \\
\hline$\Delta C_{i, t}$ & 1,654 & 0.025 & 0.167 & -0.38 & 0.906 \\
\hline$\Delta E_{i, t}$ & 1,654 & 0.031 & 0.268 & -1.117 & 1.172 \\
\hline$\Delta N A_{i, t}$ & 1,654 & 0.099 & 0.383 & -0.982 & 2.153 \\
\hline$\Delta R D_{i, t}$ & 1,654 & 0.000 & 0.001 & -0.002 & 0.004 \\
\hline$\Delta l_{i, t}$ & 1,654 & 0.012 & 0.163 & -1.368 & 0.803 \\
\hline$\Delta D_{i, t}$ & 1,654 & 0.001 & 0.037 & -0.17 & 0.138 \\
\hline$C_{i, t-1}$ & 1,654 & 0.317 & 0.47 & 0 & 2.985 \\
\hline$L_{i, t}$ & 1,654 & 0.721 & 0.493 & 0.09 & 2.681 \\
\hline$N F_{i, t}$ & 1,654 & 0.173 & 0.587 & -1.982 & 3.263 \\
\hline
\end{tabular}

Note: The variables are described in the text. The Variable column presents all the variables included in the model, except for the interaction variables. The Obs. and Average columns indicate the number of observations collected for each of the variables and its mean, respectively. Column $\sigma$ shows the standard deviation for each of the variables. Finally, the Min. and Max. columns present the minimum and maximum (extreme) data of each of the variables collected for the study. The data refer to the 20082015 period of Brazilian publicly companies traded on Brasil Bolsa Balcão (B3), with the exception of financial companies.

Source: Elaborated by the authors.

The variable $\mathrm{C}_{\mathrm{i}, \mathrm{t}-1}$ represents the lagged cash holding of the companies divided by their lagged market value. On average cash represents $31.7 \%$ of the total value of a company equity. This value indicates a high retention of money within the Brazilian companies, which may reflect the low amount of financing options available in the national financial market, in addition to the high cost of the existing ones. Consequently, keeping cash resources to finance its activities and financing may be of great value and relevance. The mean for the AV $\left(A V_{i, t}\right)$ - dependent variable of the $\mathrm{H}_{1}$ model - was positive and relevant: $5.2 \%$. From this fact, it can be inferred that in the period from 2008 to 2015, on average, the companies listed on B3 appreciated more than 5\% above the stock market index. This fact is a probable reflection of the existence of greater quantity (in number of cases) of positive extreme returns.

In addition, other interesting aspects can be listed from the analysis of the descriptive data of the complete sample. During the study period, there was an increase in the profitability $\left(\Delta \mathrm{E}_{\mathrm{i}, \mathrm{t}}\right)$ of Brazilian companies, as well as an increase in their net assets $\left(\Delta \mathrm{NA}_{\mathrm{i}, \mathrm{t}}\right)$. Similarly, there was an increase in net financing $\left(\mathrm{NF}_{\mathrm{i}, \mathrm{t}}\right)$ of companies, which probably helped in the increase in interest expenses $\left(\Delta \mathrm{I}_{\mathrm{i}, \mathrm{t}}\right)$. The typical (average) firm in our sample has a debt to (lag) equity ratio $\left(\mathrm{L}_{\mathrm{i}, \mathrm{t}}\right)$ of $72.1 \%$ and changes its dividends $\left(\Delta \mathrm{D}_{\mathrm{i}, \mathrm{t}}\right)$ by $0.1 \%$ of the lagged market value of equity each year. Finally, it is important to mention the extremely low R\&D spending in Brazil.

Regarding the dependent variable $\mathrm{AV}_{\mathrm{i}, \mathrm{t}}$, we can see, in Figure 2, its temporal evolution. Because of the proposed econometric models have panel data, this analysis may yield interesting insights. For all companies, we can observe two years with negative average data (2008 and 2014), two years with near zero data (2009 and 2015), and four more clearly positive years (2010 to 2013). As shown in Table 5, the mean value for the entire sample period was $5.2 \%$. We can infer from this graph then that the average VA of the Brazilian listed companies selected in our sample has great variability. This pattern is observed both in the group of companies that distributed only the minimum mandatory dividend and those that distributed above it. Finally, firm-year observations that pay dividends above the minimum present higher (mean) excess returns than firm-year observations that pay just the minimum. 


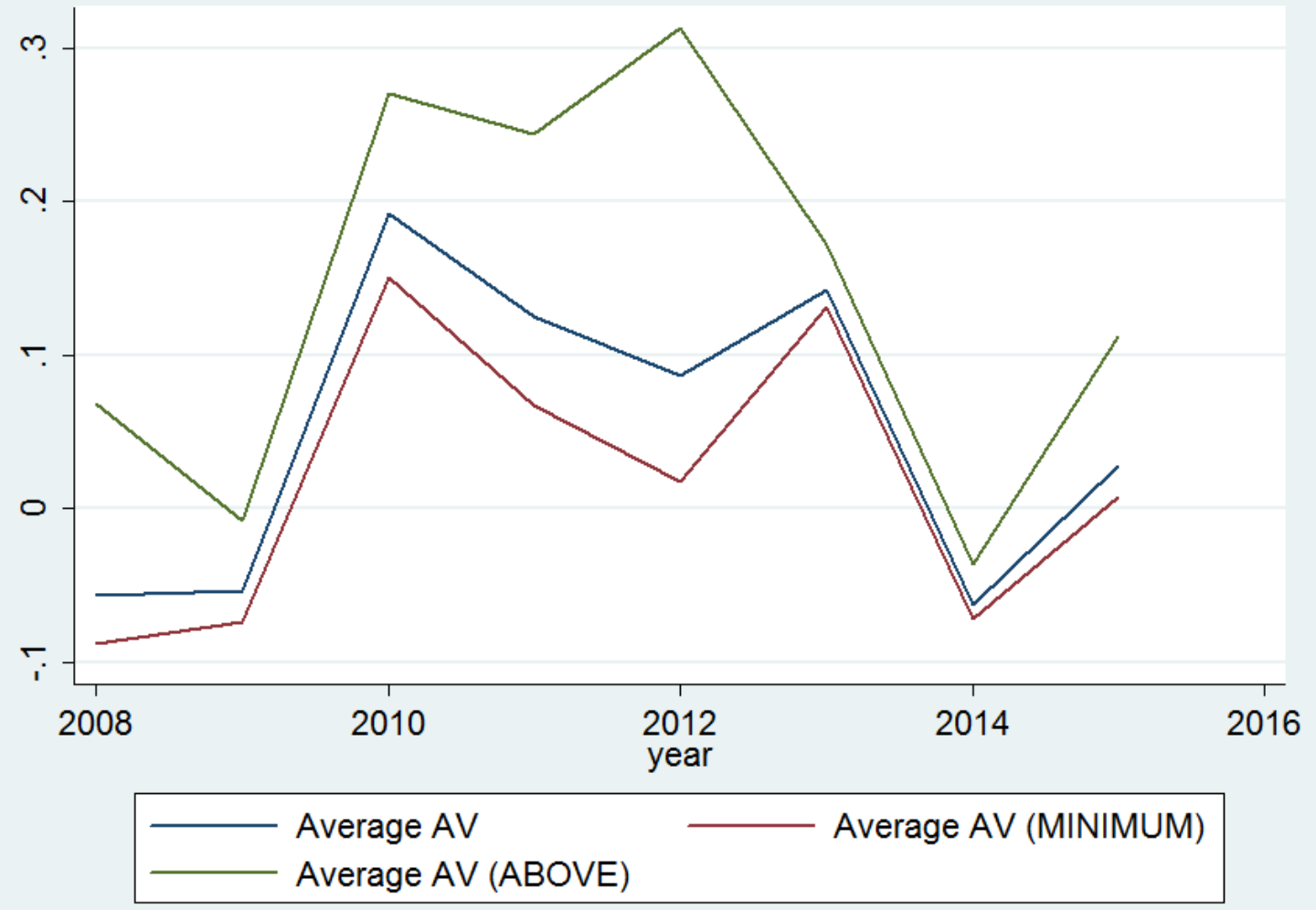

Figure 2 Temporal evolution of the mean value of the variable $A V_{i, t}$

Note: The chart is divided into three groups: Average AV reflects the data for all sample companies, Average AV (MINIMUM), those who distributed only the minimum mandatory dividend, and Average AV (ABOVE), those who distributed above the minimum.

Source: Elaborated by the authors.

In Table 2, the sample is divided among companies that distribute dividends above the mandatory minimum and those that do not. This segregation is intended to verify differences and similarities between these groups, that is, a preliminary indication of differences in the amount of cash available to these companies and other factors correlated to cash. To test if the differences between the two groups are statistically significant, a $t$ test of means was performed.

According to the results of Table 2, companies that pay dividends above the mandatory minimum are characterized by a more pronounced increase in cash and net assets over the period studied than those that pay only the minimum or do not distribute dividends (those that just comply with the legislation). These facts indicates that the first group of companies invests more and has a greater need for liquidity or can accumulate cash more easily than the second group. In average, firms that pay dividends above the mandatory also increased the proportion of distributed profits $(\Delta \mathrm{D})$ while companies that pay only the minimum or do not distribute at all decreased dividends along this time period. It is plausible that both facts are connected - the increase of money within the company may have caused (at least partially) the distribution of larger earnings.

This increase of money within the company and the increase of dividends in companies that pay above the minimum may have as source the more accentuated increase in their net external financing (NF). Additionally, these firms generate more profits $(\Delta \mathrm{E})$ in relation to the other group. These differences between groups, however, are not statistically significant. In sum, companies that pay dividends above the minimum have increased the money within the company to a greater extent and thus distributed more dividends than the rest of the sample, while the source of these resources would be both external and internal. It is also observed that these companies had higher stock market valuation appreciation (model dependent variable - AV) than the rest of the companies in the sample. This fact is indicative of positive expectations of the financial market on the future of these companies. 
Table 2

Segmented descriptive statistics of the variables selected for the $\mathrm{H}_{1}$ model

\begin{tabular}{|c|c|c|c|c|c|c|}
\hline \multicolumn{7}{|c|}{ Panel A: Companies that distribute dividends above the mandatory } \\
\hline Variable & Obs. & Average & $\sigma$ & Min. & Max. & $t$ test \\
\hline$A V_{i, t}$ & 484 & 0.150 & 0.489 & -1.224 & 2.221 & $4.8^{* * *}$ \\
\hline$\Delta C_{\mathrm{i}, \mathrm{t}}$ & 484 & 0.05 & 0.191 & -0.38 & 0.906 & $3.89^{* * *}$ \\
\hline$\Delta E_{\mathrm{i}, \mathrm{t}}$ & 484 & 0.035 & 0.235 & -1.117 & 1.172 & 0.43 \\
\hline$\Delta N A_{i, t}$ & 484 & 0.132 & 0.414 & -0.982 & 2.153 & $2.28 * *$ \\
\hline$\Delta R D_{\mathrm{i}, \mathrm{t}}$ & 484 & 0.3 & 0.937 & -1.64 & 4.28 & $6.79^{* * *}$ \\
\hline$\Delta I_{i, t}$ & 484 & 0.005 & 0.101 & -0.703 & 0.592 & -1.14 \\
\hline$\Delta D_{\mathrm{i}, \mathrm{t}}$ & 484 & 0.004 & 0.05 & -0.17 & 0.138 & $2.17^{* *}$ \\
\hline$C_{i, t-1}$ & 484 & 0.411 & 0.501 & 0.000 & 2.985 & $5.31^{* * *}$ \\
\hline$L_{i, t}$ & 484 & 0.517 & 0.18 & 0.09 & 0.885 & $-12.3^{* * *}$ \\
\hline$N F_{i, t}$ & 484 & 0.178 & 0.546 & -1.982 & 3.263 & 0.2 \\
\hline \multicolumn{7}{|c|}{ Panel B: Companies that do not pay dividends or pay only the minimum } \\
\hline$A V_{i, t}$ & 1,170 & 0.016 & 0.55 & -1.302 & 2.221 & $-4.8^{* * *}$ \\
\hline$\Delta C_{i, t}$ & 1,170 & 0.016 & 0.157 & -0.380 & 0.906 & $-3.89 * * *$ \\
\hline$\Delta E_{\mathrm{i}, \mathrm{t}}$ & 1,170 & 0.029 & 0.28 & -1.117 & 1.172 & -0.43 \\
\hline$\Delta N A_{i, t}$ & 1,170 & 0.086 & 0.37 & -0.982 & 2.153 & $-2.28^{* *}$ \\
\hline$\Delta R D_{\mathrm{i}, \mathrm{t}}$ & 1,170 & 0.005 & 0.499 & -1.64 & 4.28 & $-6.79 * * *$ \\
\hline$\Delta I_{i, t}$ & 1,170 & 0.015 & 0.18 & -1.368 & 0.803 & 1.14 \\
\hline$\Delta D_{\mathrm{i}, \mathrm{t}}$ & 1,170 & -0.000 & 0.0317 & -0.170 & 0.138 & $-2.17^{* *}$ \\
\hline$C_{i, t-1}$ & 1,170 & 0.283 & 0.453 & 0 & 2.985 & $-5.31 * * *$ \\
\hline$L_{\mathrm{i}, \mathrm{t}}$ & 1,170 & 0.794 & 0.546 & 0.09 & 2.681 & $12.3^{* * *}$ \\
\hline$N F_{\mathrm{i}, \mathrm{t}}$ & 1,170 & 0.171 & 0.602 & -1.982 & 3.263 & -0.2 \\
\hline
\end{tabular}

Note: The variables are described in the text. The Variable column presents all the variables included in the model, except for the interaction variables. The Obs. and Average columns indicate the number of observations collected for each of the variables and its mean, respectively. Column $\sigma$ shows the standard deviation for each of the variables. Finally, the Min. and Max. columns present the minimum and maximum (extreme) data of each of the variables collected for the study. Descriptive statistics have been segmented into groups: in Panel A we present descriptive statistics of companies that pay dividends above the mandatory minimum and, in Panel B, of those companies that do not pay dividends or pay only the minimum. The test column presents the $t$ statistics of the difference in means test between these groups of companies. The data refer to the 2008-2015 period of Brazilian publicly traded companies from Brasil Bolsa Balcão (B3), with the exception of financial companies. The values of the variable $\triangle R D$ were multiplied by 1,000 for better visualization.

*** indicate $p<0.01,{ }^{* *} p<0.05$, and * indicates $p<0.1$.

Source: Elaborated by the authors.

Based on these preliminary data, we now begin the analysis of the results of the proposed regressions, which are shown in Table 3. In all the regressions, the variable cash holdings $(\Delta \mathrm{C})$ attracted a positive coefficient; a positive value is assigned to the cash retention by the companies, that is, the financial market participants, during the period selected for the present research, see a positive value in the company's cash. This may reflect the national scenario in which companies have few financing options and therefore rely even more on internal sources for financing.

However, as explained in the methodology section, to test hypothesis $\mathrm{H}_{1}$, we use the terms of interaction in the model. We use the terms $\Delta \mathrm{C}_{\mathrm{i}, \mathrm{t}} \times \operatorname{DivD}_{\mathrm{i}, \mathrm{t}}$ or $\Delta \mathrm{C}_{\mathrm{i}, \mathrm{t}} \times$ Dummy $_{i, t}$ to estimate the effect of extra dividend payment in the value of cash to the company. Thus, as theorized, it is expected that the coefficient of these interactions will be negative, that is, indicating that the MVC decreases as the company decides to distribute money above the mandatory minimum. The logic behind this expectation is that if binding dividend constraint really results from financial constraints, shareholders will place a higher value on cash reserves of firms that pay just the minimum mandatory dividend than on cash reserves of firms that pay above this amount. 
Table 3

Coefficients of the regression for $\mathrm{H}_{1}$ model

\begin{tabular}{|c|c|c|c|c|}
\hline Variables & $\begin{array}{c}1 \\
A V\end{array}$ & $\begin{array}{c}2 \\
A V\end{array}$ & $\begin{array}{c}3 \\
A V\end{array}$ & $\begin{array}{c}4 \\
A V\end{array}$ \\
\hline \multirow{2}{*}{$\Delta C_{\mathrm{i}, \mathrm{t}}$} & $0.68^{* * *}$ & $0.75^{* * *}$ & $0.62^{* *}$ & $0.68^{* * *}$ \\
\hline & $(2.97)$ & (3.15) & $(2.43)$ & $(2.59)$ \\
\hline \multirow{2}{*}{$\Delta E_{\mathrm{i}, \mathrm{t}}$} & $0.16^{* * *}$ & $0.15^{* * *}$ & $0.13^{* *}$ & $0.12^{* *}$ \\
\hline & $(3.22)$ & $(3.02)$ & $(2.29)$ & (2.09) \\
\hline \multirow{2}{*}{$\Delta N A_{i, t}$} & 0.03 & 0.03 & $0.13^{* *}$ & $0.13^{* *}$ \\
\hline & $(0.71)$ & $(0.72)$ & $(2.21)$ & $(2.19)$ \\
\hline \multirow{2}{*}{$\Delta R D_{\mathrm{i}, \mathrm{t}}$} & $-37.45^{*}$ & $-36.49 *$ & $-54.52 * *$ & $-52.60 * *$ \\
\hline & $(-1.84)$ & $(-1.79)$ & $(-2.03)$ & $(-1.96)$ \\
\hline \multirow{2}{*}{$\Delta l_{\mathrm{i}, \mathrm{t}}$} & -0.01 & -0.02 & -0.00 & -0.02 \\
\hline & $(-0.08)$ & $(-0.21)$ & $(-0.02)$ & $(-0.19)$ \\
\hline \multirow{2}{*}{$\Delta D_{\mathrm{i}, \mathrm{t}}$} & $0.85^{* *}$ & $0.87^{* * *}$ & $1.01^{* *}$ & $1.08^{* * *}$ \\
\hline & $(2.57)$ & $(2.64)$ & $(2.43)$ & $(2.61)$ \\
\hline \multirow{2}{*}{$C_{i, t-1}$} & $0.18^{* * *}$ & $0.19^{* * *}$ & $0.18^{* * *}$ & $0.18^{* * *}$ \\
\hline & $(4.09)$ & $(4.21)$ & (3.49) & (3.60) \\
\hline \multirow{2}{*}{$L_{\mathrm{i}, \mathrm{t}}$} & -0.06 & -0.06 & -0.04 & -0.04 \\
\hline & $(-0.75)$ & $(-0.74)$ & $(-0.43)$ & $(-0.43)$ \\
\hline \multirow{2}{*}{$N F_{\mathrm{i}, \mathrm{t}}$} & -0.03 & -0.03 & $-0.07^{* *}$ & $-0.07^{* *}$ \\
\hline & $(-1.12)$ & $(-1.02)$ & $(-2.25)$ & $(-2.09)$ \\
\hline \multirow{2}{*}{$C_{\mathrm{i}, \mathrm{t}-1} * \Delta C_{\mathrm{i}, \mathrm{t}}$} & $-0.16^{*}$ & -0.14 & -0.09 & -0.06 \\
\hline & $(-1.82)$ & $(-1.64)$ & $(-0.87)$ & $(-0.60)$ \\
\hline \multirow{2}{*}{$L_{\mathrm{i}, \mathrm{t}} * \Delta C_{\mathrm{i}, \mathrm{t}}$} & -0.45 & $-0.49 *$ & -0.49 & $-0.53^{*}$ \\
\hline & $(-1.62)$ & $(-1.75)$ & $(-1.62)$ & $(-1.73)$ \\
\hline \multirow{2}{*}{$\Delta C_{\mathrm{i}, \mathrm{t}} * \mathrm{DivD}_{\mathrm{i}, \mathrm{t}}$} & -0.12 & & -0.17 & \\
\hline & $(-1.24)$ & & $(-1.47)$ & \\
\hline \multirow{2}{*}{$\Delta C_{i, t}{ }^{*}$ Dummy $_{i, t}$} & & $-0.27^{*}$ & & $-0.35^{*}$ \\
\hline & & $(-1.66)$ & & $(-1.80)$ \\
\hline \multirow{2}{*}{ Constant } & -0.08 & -0.08 & -0.11 & -0.11 \\
\hline & $(-1.09)$ & $(-1.12)$ & $(-1.47)$ & $(-1.50)$ \\
\hline Observations & 1,654 & 1,654 & 1,371 & 1,371 \\
\hline R-square & 0.377 & 0.378 & 0.401 & 0.402 \\
\hline Company FE & Yes & Yes & Yes & Yes \\
\hline Year FE & Yes & Yes & Yes & Yes \\
\hline Period & 2008-2015 & $2008-2015$ & $2008-2015$ & 2008-2015 \\
\hline Sample & All & All & Reduced & Reduced \\
\hline
\end{tabular}

Note: The variables are described in the text. The Variable column presents all variables included in the model. Regressions 1 , 2, 3, and 4 have as their dependent variable the $A V$, that is, the excess return of the companies. The data refer to the $2008-2015$ period of Brazilian publicly traded companies from Brasil Bolsa Balcão (B3), with regressions 1 and 2 being the full sample, and 3 and 4 with a reduced sample, that is, without utility companies. The $t$ statistic is within parentheses, where ${ }^{* * *}$ indicate $p<$ $0.01, * * p<0.05$, and * indicates $p<0.1$.

$F E=$ fixed effect.

Source: Elaborated by the authors.

In regression 1 with the complete sample, the interaction coefficient $\left(\Delta \mathrm{C}_{\mathrm{i}, \mathrm{t}} \times \mathrm{DivD}_{\mathrm{i}, \mathrm{t}}\right)$ is negative, that is, the more companies distribute dividends above the minimum required, the lower the MVC for these companies. Similarly, in regression 2, with the same sample, but using the Dummy $y_{i, t}$, variable the value of this interaction is also negative and, in this case, statistically significant at the $10 \%$ level. From the latter fact, one 
can infer a segregation in the sample, where companies that pay above the mandatory minimum have less value attributable to their cash by shareholders than companies that do not make this extra distribution. These results corroborate the view that companies that have paid dividends above the mandatory minimum are not financially constrained. They choose to use a portion of the free cash flow for distribution of extra earnings, indicating to the market that they have resources beyond what is necessary to make their projects viable. In addition and following Faulkender and Wang (2006), models 3 and 4 were estimated after excluding public utilities companies (besides financial companies) from the sample. In terms of sign and statistical significance, the main coefficients are similar to those found in the full sample (models 1 and 2). The difference in excluding utility companies from the sample lies only in the magnitude of the coefficients, where companies that pay above the minimum have even lower value assigned to their cash holdings.

After the estimation of the proposed model, we are able to measure the sensitivity of AV (returns in excess to the market benchmark) to variations on cash holdings. This step has the purpose of directly measure the AV linked to the variation in the cash, i.e., how much value is assigned by the financial market to an additional cash unit $(\Delta \mathrm{C})$. The calculation is performed through the first derivative of $\mathrm{AV}$ with respect to $\Delta \mathrm{C}$ and is demonstrated previously in equation 2. Results are summarized in Table 4.

When analyzing the results obtained with the data of the model 1 and using the variable DivD $D_{i, t}$ it is observed that the MVC of companies that have paid dividends above the mandatory minimum is smaller than the MVC of companies that have paid just the mandatory minimum. In both cases, it is statistically demonstrated that the MVC is greater than 0 , that is, for the two groups there is a positive value associated with and additional unit of cash, but this effect is smaller for companies that distribute extras dividends. However, as indicated by the results in Table 3, this difference between these two groups is not statistically significant.

Similarly, model 2 uses the same sample, but using the variable Dummy $y_{i, t}$ as representative of the extra dividend payment. With the data estimated by this model, the results also indicate that the MVC is smaller for companies that distribute extra dividends. Moreover, we cannot reject that the MVC of these companies is 0 , that is, for companies that pay above the minimum there would be no value in additional cash units, probably denoting that they are not financially restricted and have cash holdings in excess to what is needed to pursue positive net present value (NPV) projects. For companies that pay just the mandatory minimum the MVC is positive and statistically different from 0 at the $1 \%$ level. These evidences suggest that shareholders place a higher value on cash reserves of companies that pay just the mandatory minimum vis-a-vis companies that pay above the mandatory minimum, and are consistent with the view that the former firms are financial constrained and likely will use cash to fund future value-enhancing investments (Faulkender \& Wang, 2006).

\section{Table 4}

Post estimation test - Marginal value of cash (MVC)

\begin{tabular}{|c|c|c|c|c|}
\hline Model & Sample & Hypothesis & MVC & p-value \\
\hline \multirow{2}{*}{1} & Mandatory minimum & $M V C=\alpha_{1}+\alpha_{10} C_{\mathrm{i}, \mathrm{t}-1}=0$ & 0.319 & $0.007 * * *$ \\
\hline & Above mandatory & $M V C=\alpha_{1}+\alpha_{10} C_{\mathrm{i}, \mathrm{t}-1}+\alpha_{12} \operatorname{Div}_{\mathrm{i}, \mathrm{t}}=0$ & 0.274 & $0.015^{* *}$ \\
\hline \multirow{2}{*}{2} & Mandatory minimum & $M V C=\alpha_{1}+\alpha_{10} C_{i, t-1}=0$ & 0.357 & $0.004^{* * *}$ \\
\hline & Above mandatory & $M V C=\alpha_{1}+\alpha_{10} C_{\mathrm{i}, t-1}+\alpha_{12}$ Dummy $y_{\mathrm{i}, \mathrm{t}}=0$ & 0.085 & 0.598 \\
\hline \multirow{2}{*}{3} & Mandatory minimum & $V A M=\alpha_{1}+\alpha_{10} C_{i, t-1}=0$ & 0.241 & $0.077^{*}$ \\
\hline & Above mandatory & $M V C=\alpha_{1}+\alpha_{10} C_{\mathrm{i}, \mathrm{t}-1}+\alpha_{12} \operatorname{Div}_{\mathrm{i}, \mathrm{t}}=0$ & 0.192 & 0.144 \\
\hline \multirow{2}{*}{4} & Mandatory minimum & $M V C=\alpha_{1}+\alpha_{10} C_{i, t-1}=0$ & 0.275 & $0.049 * *$ \\
\hline & Above mandatory & $M V C=\alpha_{1}+\alpha_{10} C_{\mathrm{i}, \mathrm{t}-1}+\alpha_{12}$ Dummy $y_{\mathrm{i}, \mathrm{t}}=0$ & -0.072 & 0.708 \\
\hline
\end{tabular}

Note: The variables are described in the text. The Model column refers to regressions contained in Table 3. The Sample column indicates which companies were selected for the test: mandatory minimum (companies that just pay the mandatory minimum) and above required (only those companies that have distributed dividends above mandatory minimum). The Hypothesis column describes the post estimation test performed. The MVC column shows the result calculated at means of continuous variables and at observed values of nominal variables. Finally, the $p$-value column indicates the statistic of the linear post-test (on the hypothesis) performed, where *** indicate $p<0.01,{ }^{* *} p<0.05$, and * indicates $p<0.1$.

Source: Elaborated by the authors.

Models 3 and 4 restrict the sample by excluding public utilities, following Faulkender and Wang (2006). In both models 3 and 4 , the companies that distributed extra dividends have lower MVC than those that pay just the mandatory minimum. The post estimation tests suggest that is not possible to reject that companies that pay above the mandatory minimum have an additional marginal value equal to 0 . For companies that pay only 
the minimum, the MVC is positive and statistically significant at the 10\% level (model 3) and 5\% level (model 4). These results corroborate the previous ones and indicate that companies that pay dividends above the minimum have a smaller value attached to an extra unit of cash when compared to companies that pay just the mandatory minimum. One possible implication of this result is that companies that pay above the minimum have broad access to financing, which would allow for greater investments and dividend payments. In contrast, the other companies - paying just the mandatory minimum - have greater value for their cash, which probably denotes a greater dependence on internal sources for investment and financing. This extra cash would likely be used to finance value-enhancing investments for these firms. Our evidences so far suggest that mandatory dividend (or any source of withdrawal of resources from within the company) tends to have a different impact on Brazilian publicly traded companies, according to the their access to external capital markets.

Regarding the control variables in our regressions, results presented at Table 3 indicated that changes in earnings $\left(\Delta \mathrm{E}_{\mathrm{i}, \mathrm{t}}\right)$, changes in dividends $\left(\Delta \mathrm{D}_{\mathrm{i}, \mathrm{t}}\right)$, and the level of cash $\left(\mathrm{C}_{\mathrm{i}, \mathrm{t}-\mathrm{1}}\right)$ are positively and statistically related to excess stock returns. These results are qualitatively identical to those presented by Faulkender and Wang (2006). Finally and different from these authors, we found that changes in $R \& D$ expenses $\left(\Delta R D_{i, t}\right)$ are negatively related to excess stock returns.

Prior, other research used the methodology of Faulkender and Wang (2006) to investigate the value of cash holdings in different markets or periods, relating to different variables of interest. For instance, Dittmar and Mahrt-Smith (2007) showed that corporate governance has a substantial impact on the value of a dollar held by North American companies from 1990 to 2003. We can also quote Denis and Sibilkov (2009) - North American companies from 1985 to 2006 and corporate investment; Tong (2011) - North American companies from 1998 to 2005 and diversification; Steffen, Zanini, Kronbauer, and Ott (2011) - Brazilian companies from 1990 to 2008; and Louis, Sun, and Urcan (2012) - North American companies from 1974 to 2006 and accounting conservatism. In common, these papers demonstrated cash is more valuable for constrained firms. So, our results are in line with those reported by the literature on the subject, since we showed that shareholders place a higher value on cash reserves of companies that pay just the mandatory minimum and are consistent with the view that the former firms are financial constrained and likely will use cash to fund future value-enhancing investments.

\subsection{The Impact of the Mandatory Dividend on Corporate Investment $-\mathrm{H}_{2}$}

This hypothesis has the purpose of verifying whether the minimum mandatory dividend reduces the investment level of financially restricted companies, that is, those distributing only the mandatory dividend. The descriptive statistics of variables included in the model are summarized in Table 5. This table presents summary statistics for two different groups - companies that distribute dividends above the mandatory minimum (panel A) and those that do not (panel B).

Table 5

Descriptive statistics of variables for $\mathrm{H}_{2}$ model

\begin{tabular}{|c|c|c|c|c|c|c|}
\hline Variable & Obs. & Mean & Median & $\sigma$ & Kurtosis & Skewness \\
\hline \multicolumn{7}{|c|}{ Panel A: Companies that distribute "above" the mandatory dividend } \\
\hline $\ln V_{\mathrm{i}, \mathrm{t}}$ & 536 & 0.102 & 0.074 & 0.425 & 5.607 & 0.484 \\
\hline$C F_{i, t}$ & 536 & 2.04 & 0.592 & 3.603 & 7.892 & 2.448 \\
\hline$Q_{i, t-1}$ & 536 & 4.519 & 1.21 & 17.812 & 39.858 & 6.194 \\
\hline MDivi,t-1 & 536 & 0.125 & 0.124 & 0.067 & 2.913 & 0.425 \\
\hline \multicolumn{7}{|c|}{ Panel B: Companies that distribute only the "minimum" dividend } \\
\hline $\ln v_{\mathrm{i}, \mathrm{t}}$ & 271 & 0.171 & 0.121 & 0.413 & 5.443 & 0.449 \\
\hline$C F_{i, t}$ & 271 & 2.577 & 0.49 & 4.385 & 4.972 & 1.879 \\
\hline$Q_{\mathrm{i}, \mathrm{t}-1}$ & 271 & 4.859 & 1.205 & 17.57 & 38.907 & 6.016 \\
\hline MDivi,t-1 & 271 & 0.127 & 0.122 & 0.075 & 2.521 & 0.429 \\
\hline
\end{tabular}

Note: The variables are described in the text. Descriptive statistics have been segmented into groups: in Panel A we present descriptive statistics of companies that always pay dividends above the mandatory minimum, and in Panel B those companies that pay only the minimum. The Variable column presents all the variables included in the model, except for the interaction variables, and $n$ represents the number of companies in each group. The Obs. and Average columns indicate the number of observations collected for each of the variables and its mean, respectively. The column Median and $\sigma$ show the value separating the higher half from the lower half of a data sample and the standard deviation for each of the variables, respectively. Finally, the Kurtosis and Skewness columns present data about the probability distribution. The data refer to the 2008 -2015 period of Brazilian publicly traded companies from Brasil Bolsa Balcão (B3), with the exception of financial companies.

Source: Elaborated by the authors. 
This comparison is especially interesting, since both groups of companies have similar characteristics - dividend distributors, i.e., with positive results in their balance sheets, but they differ in the proportion of profits passed on to their shareholders. We observe that companies with distributions of dividends above mandatory minimum have a higher cash flow than those that distribute only the minimum. In contrast, these have higher levels of the investment variable. These results corroborate the idea that companies that pay only the minimum do so to be able to invest more, while companies that distribute above the minimum do so because they have greater internal cash flow. Finally, there is no differentiation between groups for the $\mathrm{MDiv}_{\mathrm{t}-1}$ and Tobin's $\mathrm{Q}_{\mathrm{t}-1}$ variables.

Regarding the dependent variable $\operatorname{Inv}_{\mathrm{i}, \mathrm{t}}$ we can observe, in Figure 3, its temporal evolution (analogous to the analysis made on the dependent variable of the previous model). Looking at this figure, we can clearly see that the corporate investment of the companies selected in the sample has a clear downward pattern over time, that is, companies are investing less and less, a possible reflection of the crises that occurred in Brazil and the world during the sample period. In this case, there are not remarkable differences between the groups and the entire sample.

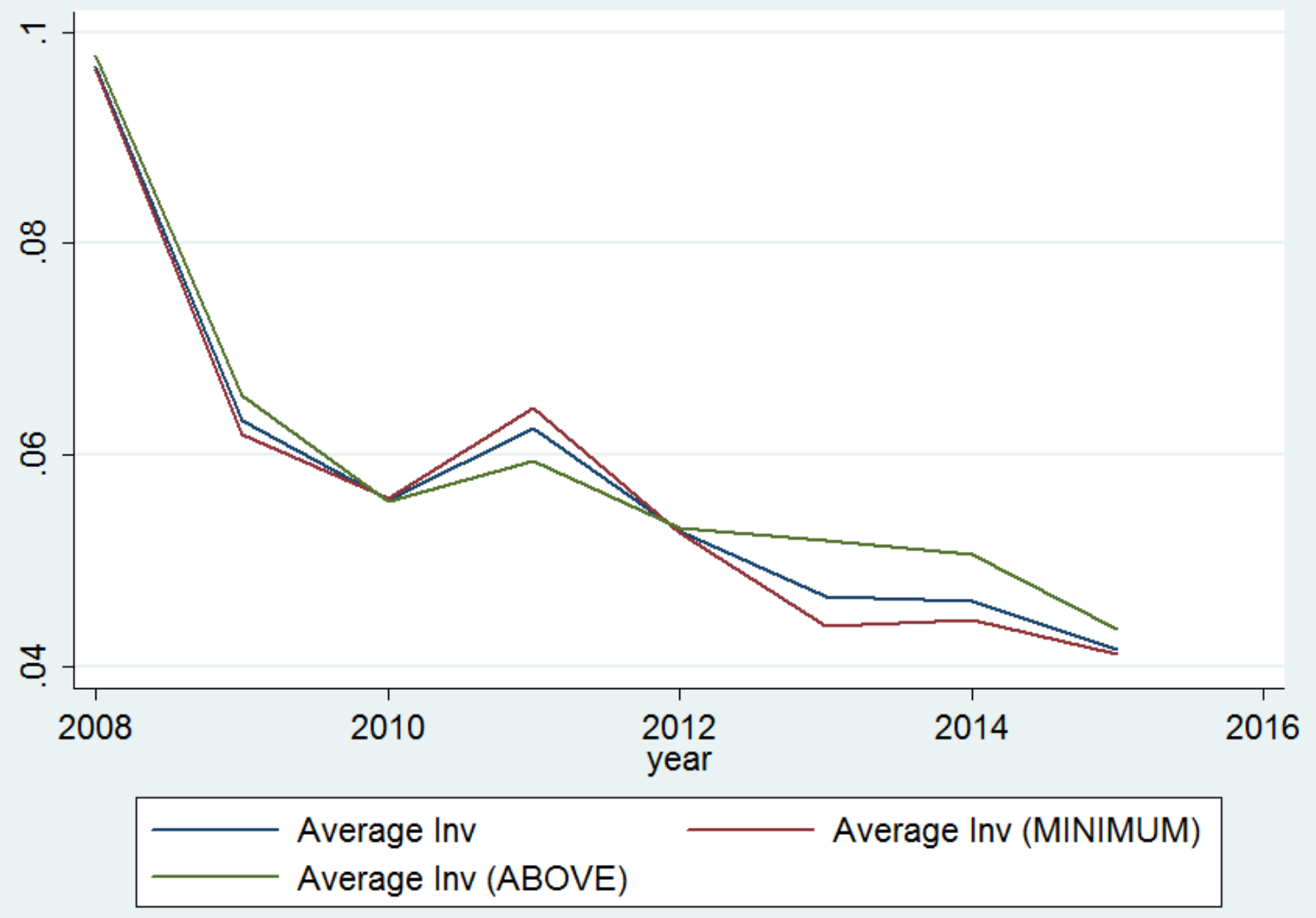

Figure 3 Temporal evolution of the mean value of the variable Invi,t

Note: The chart is divided into three groups: Average Inv reflects the data for all sample companies, Average Inv (MINIMUM), those who distributed only the minimum mandatory dividend, and Average Inv (ABOVE) those who distributed above the minimum.

Source: Elaborated by the authors.

After the sample descriptive statistical analysis, we now begin to explore the impact of mandatory dividends on the level of investment of financially constrained (unconstrained) companies, that is, those that distribute only (above) the mandatory dividend. These results are summarized in Table 6.

When we analyze the regression of the investment model 3 just using cash flow and Tobin's Q (variables widely used in investment models), both variables have positive coefficient and are statistically significant at the $1 \%$ level. This result indicates that Brazilian companies depend on cash flow (internal sources of financing) to carry out new projects. This may be a consequence, among others, of the few sources of financing existing in Brazil. Additionally, investment opportunities (Tobin's $\mathrm{Q}_{\mathrm{t}-1}$ ) affects positively corporate investment, corroborating with our initial expectations. 
The cash flow used to distribute the mandatory dividend could also be (instead) used to finance projects economically favorable to companies. Therefore, dividends can act as limiting agents of investments, thus damaging shareholders themselves. Therefore, in our second model, we introduce the variable $\mathrm{MDiv}_{\mathrm{i}, \mathrm{t}-1}$ - mandatory dividend. This variable negatively affects corporate investment accordingly to our econometric model. This fact corroborates with the initial expectations of the research, although its coefficient is not statistically significant.

Specifically in Brazil, the legislation imposes a minimum compulsory distribution of dividends and this obligation does not consider the different realities faced by companies. Companies that distribute only the mandatory dividend send very strong signals to the market. These companies, by their own criteria, decide to retain as much of their profits as possible in company projects, without distributing them to their shareholders. Thus, it was expected that, for this group of companies, the mandatory dividend have a larger impact on the firm's investment, since these firms demonstrate that they need the maximum possible of their internal resources to fund these investments.

Table 6

Coefficients of the regression for $\mathrm{H}_{2}$ model

\begin{tabular}{|c|c|c|c|c|c|}
\hline \multirow{2}{*}{ Variable } & 1 & 2 & 3 & 4 & 5 \\
\hline & $\ln v_{i, t}$ & $\operatorname{In} v_{i, t}$ & $\ln v_{i, t}$ & $\operatorname{In} \mathrm{v}_{\mathrm{i}, \mathrm{t}}$ & $\ln v_{i, t}$ \\
\hline \multirow{2}{*}{$C F_{i, t}$} & $0.12^{* * *}$ & $0.13^{* * *}$ & $0.13^{* * *}$ & $0.13^{* * *}$ & $0.12^{* * *}$ \\
\hline & $(8.92)$ & $(8.22)$ & (8.30) & $(8.40)$ & $(7.41)$ \\
\hline \multirow{2}{*}{$Q_{i, t-1}$} & $0.00^{* * *}$ & $0.00^{* * *}$ & $0.00^{* * *}$ & $0.00 * * *$ & $0.00^{* * *}$ \\
\hline & $(4.42)$ & $(4.00)$ & $(4.10)$ & (3.98) & (3.00) \\
\hline \multirow{2}{*}{$M \operatorname{Div}_{i, t-1}$} & & -0.16 & $-0.19^{*}$ & $-0.26^{* *}$ & -0.02 \\
\hline & & $(-1.60)$ & $(-1.87)$ & $(-2.40)$ & $(-0.20)$ \\
\hline \multirow{2}{*}{$\min _{i, t-1}$} & & & 0.00 & -0.00 & -0.00 \\
\hline & & & $(1.44)$ & $(-0.37)$ & $(-0.42)$ \\
\hline \multirow{2}{*}{$\operatorname{MDiv}_{i, t-1} * \min _{i, t-1}$} & & & & $0.40^{*}$ & 0.29 \\
\hline & & & & $(1.74)$ & $(1.45)$ \\
\hline \multirow{2}{*}{ Constant } & $0.08^{* * *}$ & $0.07^{* * *}$ & $0.07^{* * *}$ & $0.07^{* * *}$ & $0.07^{* * *}$ \\
\hline & $(10.55)$ & $(9.56)$ & $(9.51)$ & $(9.58)$ & $(6.04)$ \\
\hline Observations & 1,388 & 1,388 & 1,388 & 1,388 & 1,388 \\
\hline R-squared & 0.1347 & 0.1424 & 0.1437 & 0.1455 & 0.1388 \\
\hline Industry dummy & Yes & Yes & Yes & Yes & Yes \\
\hline Year dummy & Yes & Yes & Yes & Yes & Yes \\
\hline Sample & 2008-2015 & 2008-2015 & 2008-2015 & 2008-2015 & 2008-2015 \\
\hline Data & Pooled & Pooled & Pooled & Pooled & Panel \\
\hline Estimation & OLS & OLS & OLS & OLS & R.E \\
\hline
\end{tabular}

Note: The variables are described in the text. The Variable column show all variables included in the model. The dependent variable is investment (Inv), measured by the annual growth of fixed assets. Industry dummy represents the presence of a binary control variable for the corporate economic sector, and the year dummy indicates the presence of the binary variable representative of the sample years. The data refer to the 2008-2015 period of Brazilian publicly traded companies from Brasil Bolsa Balcão (B3), excluding financial companies. Line Data indicates the type of data used in the model: pooled or panel. The $t$ statistic is within parentheses, where ${ }^{* * *}$ indicate $p<0.01,{ }^{* *} p<0.05$, and ${ }^{*}$ indicates $p<0.1$.

Source: Elaborated by the authors.

Therefore, in our third and fourth models we introduce the variables $\min _{\mathrm{i}, \mathrm{t}-1}$ and $\mathrm{MDiv}_{\mathrm{i}, \mathrm{t}-1} \times \min _{\mathrm{i}, \mathrm{t}-1}$, respectively. When $\min _{\mathrm{i}, \mathrm{t}-1}$ is included (model 3 ), $\mathrm{MDiv}_{\mathrm{i}, \mathrm{t}-1}$ attract a negative and statistically significant coefficient. This result suggest that mandatory dividends reduce firms' investment, irrespective of their financial status. The not statistically significant coefficient of $\min _{i, t-1}$ indicates that investment of companies that pay just the mandatory minimum are not different from the investment of companies that pay above this minimum.

Model 4 also includes the interaction $\mathrm{MDiv}_{\mathrm{i}, \mathrm{t}-1} \times \min _{\mathrm{i}, \mathrm{t}-1}$. The main objective of this model is to demonstrate the differential impact of mandatory dividend $\left(\mathrm{MDiv}_{\mathrm{i}, \mathrm{t}-\mathrm{1}}\right)$ on corporate investment between Brazilian companies 
that pay only the mandatory dividend and those that pay above this minimum. From the negative and statistically significant coefficient of the variable $\mathrm{MDiv}_{\mathrm{i}, \mathrm{t}-1}$, we can deduce that the mandatory dividend reduces the investment of Brazilian companies that pay above the mandatory minimum. This result contradicts our expectations. The positive and statistically significant coefficient of the interaction term indicates that the mandatory dividend does not have a negative impact on the corporate investment for companies that distribute only the mandatory dividend, the opposite of what we expected initially. These results suggest that mandatory dividends affect adversely the investments of firms that pay above the mandatory minimum and do not harm the investments of firms that pay just the minimum. If we believe that a binding dividend constraint signals financial constraints, the roles of these two groups of companies should be reversed. In sum, these evidences strongly reject our hypothesis $\mathrm{H}_{2}$.

Previously, a number of national empirical studies have highlighted the impact of cash flow, investment opportunities, and financial constraints on corporate investment (Aldrighi \& Bisinha, 2010; Kirch, Procianoy, \& Terra, 2014; Machado, 2016). In these studies, as a rule, we note that cash flow and investment opportunities positively impact corporate investment and that financial constraints directly affect the phenomenon studied. The results of our research are in line with the findings of other Brazilian researches cited above. However, we have advanced as we incorporate into the traditional model the variables representing mandatory dividend payment - a significant source of cash flow generated by companies that could directly impact firms' investment policy.

How can we reconcile these conflicting results of hypotheses $\mathrm{H}_{1}$ and $\mathrm{H}_{2}$ ? As we argue in the introductory section, we believe that our tests involving the MVC are a better way to analyze the effects of mandatory dividends on firm financial behavior, since the dependent variable is set by market investors and not by the same persons that decide about the dividend police. This is not the case when we analyze the investment decision: this variable is set by the same persons that decide about the dividend police. In few words, dividend and investment are jointly determined and so dividend is endogenous in the investment equation. This endogeneity problem precludes us of estimating the real (unbiased) effect of mandatory dividend on corporate investment. Taking these considerations into account, we are confident that our results regarding $\mathrm{H}_{1}$ reveal the real behavior of Brazilian firms and should receive more attention than those regarding $\mathrm{H}_{2}$.

Finally, following the suggestions of an anonymous referee and as a robustness test, we rerun our original regressions using a different approach to separate observations in groups. Instead of separating observations in two groups - firms-years that pay just the mandatory minimum and firms-years that pay above mandatory minimum - we separate firms in three groups: firms that always (during the entire sample period) pay above the mandatory (above group), firms that sometimes pay above and at other times pay just the minimum (vary group), and firms that always pay the mandatory minimum (min group). Our original criteria recognize that firms can change their financially constraint status over time, while this alternative criteria suggest that the long-run payout behavior is what could drive our main results. If we can assume that firms in the min group are financially constrained, firms in the vary group are partially financially constrained, and firms in the above group are financially unconstrained, these new results (omitted, but available upon request) are in line with those we present in the main text. For example, regarding the $\mathrm{MVC}$, this value decreases as we move from the min group to the vary group and reduces even more when we move from the min group to the above group (although this last difference is not statistically significant, probably because of the low number of observations/firms in this group). In our view, these new and novel results are complementary and reinforce the conclusions we draw from the initial results that we keep in the main text.

\section{FINAL COMMENTS}

The purpose of our research was to verify the impact of mandatory dividends on Brazilian publicly traded companies' internal funding, focusing on both the value of cash holdings and the impact on corporate investment. We accomplish this by estimating firm value and investment regressions for a sample of 1,654 dividend distributions from 2008 to 2015.
Our results indicate that mandatory dividend has an impact on the companies' internal funding. They show that companies paying just the minimum dividend have higher value attached to an extra unit of cash, i.e., they have a greater dependence on internal sources for investment and financing in these companies, and also indicate that mandatory dividend has a negative 
impact on corporate investment, but only for companies paying dividends above the minimum, contrary to our expectations.

We argue that the MVC approach is a more effective way to test the impact of regulation on corporate financial decisions, and this last evidence may be the result of endogeneity problems in investment regressions. Therefore, we are confident that our results reveal that mandatory dividends could be detrimental to some firms, precluding them from making ideal investment and financing decisions. To the best of our knowledge, we are the first to use the MVC approach to study the impact of mandatory dividends on firm financial decisions. For all these reasons, we believe that our study contributes to the literature, adding novel empirical evidences on the (probably) non-intended consequences of regulation on business matters.

Considering the Brazilian context, where sources of financing are expensive and scarce, this evidence obtained by the present research has great relevance for the financial market. Based on this study, domestic and foreign investors will have more accurate information on the impact of the mandatory dividend law on the companies to be invested. Managers, especially from foreign companies who would like to establish a base in Brazil, will also have more inputs on withdrawing part of their companies' cash flow. Even governments that adopt or intend to adopt a mandatory dividend can use these findings to make the most appropriate decision for their countries. Not least, the present research serves as another step in the academy's understanding of this legal mechanism, an important law that has generated few academic studies - perhaps for its complexity and lack of data.

It is important to emphasize that the law aims to protect the minority investor against the expropriation of resources within the firms by insiders. However, in dealing with all cases equally, legislation ends up harming companies that rely on these resources for their financing, thereby damaging their shareholders.

\section{REFERENCES}

Abel, A. B., \& Eberly, J. C. (2011). How q and cash flow affect investment without frictions: An analytic explanation. The Review of Economic Studies, 78(4), 1179-1200.

Acharya, V. V., Almeida, H., \& Campello, M. (2007). Is cash negative debt? A hedging perspective on corporate financial policies. Journal of Financial Intermediation, 16(4), 515-554.

Aldrighi, D. M., \& Bisinha, R. (2010). Restrição financeira em empresas com ações negociadas na Bovespa. Revista Brasileira de Economia, 64(1), 25-47.

Almeida, H., Campello, M., \& Weisbach, M . S. (2004). The cash flow sensitivity of cash. The Journal of Finance, 59(4), 17771804.

Coelho, F. U. (2002). Curso de direito comercial (Vol. 1). São Paulo, SP: Saraiva.

Denis, D. J., \& Sibilkov, V. (2009). Financial constraints, investment, and the value of cash holdings. The Review of Financial Studies, 23(1), 247-269.

Dittmar, A., \& Mahrt-Smith, J. (2007). Corporate governance and the value of cash holdings. Journal of financial economics, 83(3), 599-634.

Fama, E. F., \& French, K. R. (1998). Taxes, financing decisions, and firm value. Journal of Finance, 53(3), 819-843.

Faulkender, M., \& Wang, R. (2006). Corporate financial policy and the value of cash. The Journal of Finance, 61(4), 19571990.

Fazzari, S., \& Petersen, B. C. (1993). Working capital and fixed investment: New evidence on financing constraints. The RAND Journal of Economics, 24(3)328-342.

Fazzari, S., Hubbard, R. G., \& Petersen, B. (1988). Investment, financing decisions, and tax policy. The American Economic Review, 78(2)200-205.
Fazzari, S., Hubbard, R. G., \& Petersen, B. (2000). Investmentcash flow sensitivities are useful: A comment on Kaplan and Zingales. Quarterly Journal of Economics, 115(2)695-705.

Gilchrist, S., \& Himmelberg, C. P. (1995). Evidence on the role of cash flow for investment. Journal of Monetary Economics, 36(3), 541-572.

Gomes, J. F. (2001). Financing investment. American Economic Review, 91(5), 1263-1285.

Hubbard, R. G. (1997). Capital-market imperfections and investment. Journal of Economic Literature, 36(1), 193-225.

Kaplan, S., \& Zingales, L. (1997). Do investment-cash flow sensitivities provide useful measures of financing constraints? The Quarterly Journal of Economics, 112(1), 169-215.

Kaplan, S., \& Zingales, L. (2000). Investment-cash flow sensitivities are not valid measures of financing constraints. The Quarterly Journal of Economics, 115(2), 707-712.

Kirch, G., Procianoy, J. L., \& Terra, P. R. S. (2014). Restrições financeiras e a decisão de investimento das firmas brasileiras. Revista Brasileira de Economia, 68(1), 103-123.

La Porta, R., Lopez-de Silanes, F., Shleifer, A., \& Vishny, R. (1998). Law and finance. Journal of Political Economy, 106(6), 1113-1155.

La Porta, R., Lopez-de Silanes, F., Shleifer, A., \& Vishny, R. (2000). Agency problems and dividend policies around the world. The Journal of Finance, 55(1), 1-33.

Lei n. 6.404, 15 de dezembro de 1976. (1976, 17 de dezembro). Dispõe sobre as Sociedades por Ações. Retrieved from http:// www.planalto.gov.br/ccivil_03/leis/L6404consol.htm

Lewellen, J., \& Lewellen, K. (2016). Investment and cash flow: New evidence. Journal of Financial and Quantitative Analysis, 51(4), 1135-1164. 
Louis, H., Sun, A. X., \& Urcan, O. (2012). Value of cash holdings and accounting conservatism. Contemporary Accounting Research, 29(4), 1249-1271.

Machado, K. D. S. R. (2016). Análise da sensibilidade do investimento em relação ao fluxo de caixa: um estudo nas empresas da indústria brasileira listadas na BMßFBOVESPA entre os anos 2004 e 2014 (Master's Dissertation). Universidade Federal de São Carlos. Retrieved from https://repositorio.ufscar.br/handle/ ufscar $/ 8520$ ? show=full

Machado, M. A. V., \& Medeiros, O. R. (2011). Modelos de precificação de ativos e o efeito liquidez: evidências empíricas no mercado acionário brasileiro. Revista Brasileira de Finanças, 9(3), 383-412.

Martins, T. C., \& Novaes, W. (2012). Mandatory dividend rules: Do they make it harder for firms to invest? Journal of Corporate Finance, 18(4), 953-967.

Noda, R. F., Martelanc, R., \& Securato, J. R. (2014). Eficiência da carteira de mercado no plano média-variância. Revista Brasileira de Finanças, 12(1), 67-88.
Pinkowitz, L., \& Williamson, R. (2004). What is a dollar worth? The market value of cash holdings [Working Paper]. Georgetown University.

Souza, D. H., Peixoto, F. M., \& Santos, M. A. (2016). Efeitos da governança corporativa na distribuição de dividendos: um estudo em empresas brasileiras. Advances in Scientific and Applied Accounting, 9(1), 58-79.

Steffen, H. C., Zanini, F. A. M., Kronbauer, C. A., \& Ott, E. (2014). Administração do capital de giro: um estudo sobre os fatores que influenciam na criação de valor para a empresa. Contabilidade Vista \& Revista, 25(1), 15-33.

Tong, Z. (2011). Firm diversification and the value of corporate cash holdings. Journal of Corporate Finance, 17(3), 741-758.

Vancin, D. (2013). Dividendos: a vontade de pagar, ou não, das empresas brasileiras de capital aberto (Master's Dissertation). Universidade Federal do Rio Grande do Sul.

Vancin, D., \& Procianoy, J. (2016). Os fatores determinantes do pagamento de dividendos: o efeito do obrigatório mínimo legal e contratual nas empresas brasileiras. Revista Brasileira de Finanças, 14(1), 89-123. 